Western Washington University Western CEDAR

\title{
LRE re-examined: misinterpretations and unintended consequences
}

Keith J. Hyatt

Western Washington University, keith.hyatt@wwu.edu

John Filler

Follow this and additional works at: https://cedar.wwu.edu/woodring_dei

Part of the Education Commons

\section{Recommended Citation}

Keith J. Hyatt \& John Filler (2011) LRE re-examined: misinterpretations and unintended consequences, International Journal of Inclusive Education, 15:9, 1031-1045, DOI: 10.1080/13603116.2010.484509

This Article is brought to you for free and open access by the Woodring College of Education at Western CEDAR. It has been accepted for inclusion in Woodring Scholarship on Diversity, Equity, Inclusion by an authorized administrator of Western CEDAR. For more information, please contact westerncedar@wwu.edu. 


\title{
LRE re-examined: misinterpretations and unintended consequences
}

\author{
Keith J. Hyatt ${ }^{\mathrm{a} *}$ and John Filler ${ }^{\mathrm{b}}$ \\ ${ }^{a}$ Department of Special Education, Western Washington University, Bellingham, USA; \\ ${ }^{b}$ Department of Special Education, University of Nevada, Las Vegas, USA
}

The least restrictive environment (LRE) requirement has been one of the major pillars of special education law in the USA since its enactment in 1975 and has proven to be one of the most contentious principles. Absent a decision by the US Supreme Court or further clarification in the wording of the law itself, it is likely that the debate will continue. This discussion is particularly important because misapplication of the LRE principle can result in a violation of civil rights and deprive children of a free appropriate public education. A review of the historical background of LRE, the Individuals with Disabilities Education Act and relevant court cases supports the contention that the general education setting is the LRE for every child but not necessarily the appropriate placement for all children.

Keywords: least restrictive environment; inclusion; individualised education programme; continuum of alternative placements; special education; Individuals with Disabilities Education Act

Since the 1975 enactment of special education law in the USA, the concept of least restrictive environment (LRE) has been one of the six guiding principles of the legislation (Turnbull and Turnbull 1998). Briefly, LRE requires that children with disabilities be educated in the regular education environment to the maximum extent appropriate unless their educational needs cannot be met in that setting, even with the use of supplementary aids and services. The concept remains one of the most contentious sections of the law (Danile 1997; Turnbull, Stowe, and Huerta 2007) and has been interpreted differently by the Federal Circuit Courts (Evangelista 1998; Palley 2006). There are 13 Federal Circuit Courts, sometimes referred to as Appellate Courts, with jurisdictions over different geographic areas. The only court with more authority is the US Supreme Court, and the decisions of that court are binding throughout the nation. Since the US Supreme Court has not ruled on LRE (Turnbull, Stowe, and Huerta 2007), decisions guiding determination of educational placement for children with disabilities are largely subject to different 'tests' depending upon the Circuit in which the case is heard.

Taylor (1988) noted that courts, legislatures and administrative bodies have relied upon professional testimony and literature when considering LRE. In San Antonio School District v. Rodriguez (1973), the US Supreme Court stated that-courts lack the 
"specialized knowledge and experience" necessary to resolve "persistent and difficult questions of educational policy". LRE certainly qualifies as a persistent and difficult issue in educational policy with those arguing that the LRE is the general education classroom for all children (Sailor et al. 1989), others claiming that LRE is different for different children (Fuchs and Fuchs 1994; Kauffman 1995; Kauffman and Hallahan 2005a, 2005b) and still others arguing that the LRE for a particular student may change over time (Heward 2006). The imprecise use of the term LRE is likely a contributing factor in the debate. For example, Baird (2006), an attorney who represents school districts in LRE cases, stated that 'regular classroom with no supplementary aids or services is LRE for any child'. However, later in the same training video, she stated that 'each child's LRE is different'. It is clearly impossible for both of these assertions to be accurate. Similarly, Yell stated, 'least restrictive environment is not a particular setting' $(2006,310)$ but later noted that 'the general education environment is considered the least restrictive setting' (310). Still other authors have warned that placement in the general education setting alone does not ensure a least restrictive placement if within that environment there is no meaningful participation in activities typical for such a setting (Hamre-Nietupski and Nietupski 2008). As Petrou, Angelides, and Leigh (2009) have noted, 'marginalisation' may occur in spite of our best efforts to provide opportunities for meaningful participation. Clearly, placement in the general education setting is not sufficient for there to be the least possible restriction upon educational opportunity but most would see it as an important, if not necessary, precondition.

The purpose of this paper is to address continuing controversy by providing a clear and coherent explanation of the concept of LRE, differentiating it from the continuum of alternative placements (a subsection of the LRE provision in the federal regulations), and making the case that the LRE for all children, regardless of disability, is the regular education environment while acknowledging that placement in the LRE may not be appropriate for all children. In fact, mandating that all children with disabilities must be educated in the regular education environment would be a violation of the LRE section of American law which requires access to alternative settings if the child's needs cannot be met in the general education setting with the use of supplementary aids and services. It is imperative that educators of students with disabilities come to a consensus on the meaning of LRE. In the USA this concept represents a pivotal civil rights issue that must be balanced with the provision of a free appropriate public education (FAPE) as required by Individuals with Disabilities Education Act (IDEA) of 2004. Failure to understand and correctly implement the requirements of LRE can result in illegal and unnecessary infringements upon the civil liberties of students with disabilities by placing them in settings more restrictive than necessary to meet their educational needs. The goals of this review will be accomplished by describing the historical background of services to individuals with disabilities, background of LRE, the IDEA, professional opinion and findings from case law.

This is not a paper on inclusion. An excellent discussion of how the term 'inclusion' has evolved in the USA and how the widespread preference for education in the general education classroom has emerged has recently been provided by Thomazet (2009). However, as Thomazet noted the strong Congressional preference for placement in the general education setting is apparent from the first appearance in 1975 of the Education for All Handicapped Children Act (EAHCA), today known as IDEA and reauthorised as Public Law 108-446. 
In the preamble to the IDEA 04 (Public Law 108-446), Congress noted the following:

601 (c) (1): Disability is a natural part of the human experience and in no way diminishes the right of individuals to participate in or contribute to society. Improving educational results for children with disabilities is an essential element of our national policy of ensuring equality of opportunity, full participation, independent living, and economic self-sufficiency for individuals with disabilities.

601 (c) (5): Almost 30 years of research and experience has demonstrated that the education of children with disabilities can be made more effective by:

(A) having high expectations for such children and ensuring their access to the general education curriculum in the regular classroom, to the maximum extent possible;

(B) ... families of children to have meaningful opportunities to participate in the education of their children;

(C) ... special education can become a service for such children rather than a place where such children are sent;

(D) providing appropriate special education and related services, and aids and supports in the regular classroom, to such children, whenever appropriate; and

(E) supporting high-quality, intensive preservice preparation and professional development for all personnel who work with children with disabilities.

These statements clearly demonstrate the Congressional intent that children with disabilities should be educated in the general education setting to the maximum extent appropriate and emphasise that special education is a service, or set of services, not a place to send a child. Additionally, those special education services needed by eligible children should be provided in the general education classroom whenever appropriate, with the ultimate goal of providing students with disabilities the skills needed to participate in society upon cessation of special education services. Certainly, not all students with disabilities are able to participate in the same manner as students without disabilities, but education should prepare them for meaningful participation and membership in the community. The preamble also requires that all personnel working with children with disabilities receive the training needed to enable them to provide educational opportunities for children with disabilities. This is an important requirement, because it highlights that the education of children with disabilities is not the sole responsibility of special education teachers but is a responsibility shared by both regular and special educators. The preamble also supports the following conclusions of the President's Commission on Excellence in Special Education (2002): (1) general and special education share the responsibility of educating students with disabilities, (2) special education is a service, and (3) students with disabilities are general education students.

\section{Historical background}

The history of education for persons with disabilities has been covered comprehensively by others (e.g. Osgood 2008; Turnbull and Turnbull 1998; Yell 2006), so only a brief highlight of issues directly related to the principle of LRE and the exclusion of children with disabilities from public education is reviewed here. Since the US Constitution did not expressly authorise the federal government to provide educational services, that right has traditionally been left to the states. However, states were required to implement policies that were in agreement with the US Constitution. 
Early court decisions and legislative actions regarding the education of children with disabilities followed a path similar to that of racial segregation. The 1896 US Supreme Court decision in Plessy v. Ferguson provided legal authority and recognition of the concept of 'separate but equal' in issues of race. The practice of state-authorised segregation was reflected in American schools and had important effects on the education of children with disabilities. As states began to provide education, and eventually require compulsory attendance, students with disabilities were typically excluded from compulsory attendance laws, and some state legislatures enacted statutes that specifically authorised school districts to exclude children with disabilities from public school settings (Yell 2006). As with the legal sanction of racial segregation and exclusion, the US Supreme Court also recognised that a state could legally exclude children with disabilities from public education. In the 1925 decision in Pierce v. Society of Sisters, the US Supreme Court ruled on a case specifically concerned with whether a state could require compulsory attendance at public schools but not recognise attendance at parochial schools. The Court ruled that compulsory attendance could be enforced, but the state was not authorised to require public education at the expense of a parochial education. So, while this case really had to do with government entanglement in religion, the Court deemed it necessary to explicitly note that Oregon's compulsory attendance law did not apply to children with disabilities, 'there are exemptions - not especially important here - for children who are not normal'.

However, the law is not static and in 1954, the US Supreme Court issued a landmark decision in Brown v. Board of Education. The Court reversed its previous declaration of 'separate but equal' outlined in Plessy v. Ferguson and stated, 'we conclude that in the field of public education the doctrine of "separate but equal" has no place. Separate educational facilities are inherently unequal'. In making its decision, the Court noted the changes in public policy and scientific understanding that led to the determination that one group of people was not inferior to another. Brown was a major judicial decision that not only fuelled the civil rights movement, but also offered significant support to the disability rights movement (Turnbull and Turnbull 1998). Since the court made no effort to narrowly proscribe its interpretation to issues of race, placement of students with disabilities in wholly segregated settings is equally questionable. Turnbull and Turnbull noted that one only needs to substitute 'nondisabled' for 'white' and 'disabled' for 'negro' in the original language of the Brown decision to note how easily this decision could be extended to the education of children with disabilities.

With Brown as a basis, the stage was set for change in the provision of services to children with disabilities (Yell 2006). The disparities in educational opportunities for students with disabilities were being exposed, particularly for those with the most significant disabilities. For example, in 1966, Blatt and Kaplan released a pictorial expose on the state of care inside an institution for persons with disabilities. The pictures taken secretly from a camera hidden in Kaplan's belt, and descriptive comments clearly portrayed the deplorable conditions in which citizens with the least ability or opportunity to advocate for themselves had been placed. This expose and others (e.g. Rivera 1972) documented the fallacy of automatically equating more restrictive placements with more specialised services and invigorated emerging advocacy work on behalf of institutionalised people with disabilities.

At about the same time suggestions for the provision of special education services in least restrictive settings were being discussed in the professional literature. Reynolds (1962) provided a framework for special education placements which is reflected in the continuum of alternative placements provision that has been a part of 
the LRE section of special education law since its enactment in 1975. This provision requires that placement options from least (regular class) to most restrictive (institution) must be available to children with disabilities if needed to provide educational benefit.

The continuum was refined by Deno (1970) and renamed 'the cascade system of special education service'. The model envisioned that most children with disabilities would be in regular classrooms while those needing more intensive services would be placed in more restrictive setting along a continuum, ranging from regular classes for those with 'mild' disabilities to institutions for individuals with 'severe' disabilities. Descriptions of the model clearly indicated that the most restrictive placements were those envisioned to provide the most specialised services, and there were no considerations for bringing those highly specialised services to less restrictive settings. Rather, children were automatically moved from least to most restrictive placements based solely on the level of support needed. This 'cascade model' was also reflected in the idea that prerequisite skills were necessary for placement in the regular education class. In essence, this model supported the contention that students with disabilities had to 'earn' or 'learn' their way into the general education classroom, a clearly discriminatory standard not typically applied to students without disabilities.

This model, the basis for the continuum of alternative placements which is consistently confused with LRE, was viewed by some as a progressive approach at the time. However, not all in the field agreed. Taylor (1988) and Biklen (1982) argued against the continuum and identified numerous problems associated with it. Taylor (2001) reemphasised his earlier concerns with the continuum, noting that it continues to be flawed, particularly for individuals with severe disabilities. His concerns included the following regarding reliance on the continuum: (1) the continuum confuses segregation with intensity of services by implying that the most intensive supports require segregation, (2) the continuum provides an assumption that the rights of people with disabilities will be restricted, the decision is only how much, and (3) the continuum is based on a 'readiness' model requiring individuals to earn their way back to less restrictive settings.

Organised advocacy groups also began demanding fair treatment of individuals with disabilities as well as community membership rather than segregation and isolation. In 1972 the Pennsylvania Association for Retarded Citizens (PARC) challenged the state of Pennsylvania for not providing children with mental retardation with a meaningful education and for violating the children's equal protection rights under the 14th Amendment to the US Constitution (PARC v. Commonwealth of Pennsylvania). In a consent decree, both sides agreed that children with mental retardation would be provided numerous rights, including an individualised education programme (IEP), the right to due process and placement based upon a careful determination of educational needs. In Mills $v$. DC, the guarantees provided in PARC were extended to include all children with disabilities regardless of diagnostic category (Mills $v$. District of Columbia Board of Education 1972). The findings from Mills were a basis upon which the procedural safeguards of the looming special education law were built and emphasised that placement in a regular class was preferable to special class which was preferable to special school. Despite the outcome of PARC and Mills, the educational opportunities for individuals with disabilities continued to be limited (Yell 2006).

Section 504 of The Rehabilitation Act of 1973, a civil rights law, was amended in 1975 to specifically prohibit agencies receiving federal funds from discriminating against otherwise qualified individuals solely on the basis of disability. In 1975, 
Congress passed the first comprehensive special education law, Public Law 94-142 (PL 94-142), also known as the EAHCA. This legislation provided funding and guidelines for the provision of special education services for eligible children from five years of age to 21 years of age. Turnbull and Turnbull (1998) noted that by passing this law, Congress recognised the need to enforce the equal protection clause of the Constitution. Accordingly, school district practices of exclusion and discriminatory treatment solely on the basis of disability were no longer allowed. The EACHA, now called the IDEA, has been amended several times, most recently in 2004. IDEA 04 provides for early intervention services for eligible children and families from birth to two years of age (Part $C$ of the law) and special education services for children from age 3 to 21 (Part B of the law), with a goal of providing a seamless programme of support.

In 1982, Biklen argued that LRE was a deceptively simple concept; however, given the continued controversy, it appears that others have not seen it to be as simple as he thought it to be. The controversy may, in part, be due to a somewhat vague definition of LRE provided in the law and regulations, as well as the evolution of educational practices since passage of the EAHCA. Villa and Thousand (2003) noted that when first passed, many interpreted the law to require 'mainstreaming'. The term denoted the acceptance of students with disabilities into 'mainstream' classes when they could keep up with relatively few or no supports or curricular modifications. In essence, this was a type of 'sink or swim' approach to providing special education services to children with disabilities with special education viewed as a place where children go rather than as services that follow children. In the 1980s the concept of LRE included the practice of 'integration', a term that recognised an increased emphasis on serving students with more severe disabilities in the regular school setting rather than at special schools. Finally, in the 1990s, the interpretation of LRE underwent another modification, known as 'inclusion'. Inclusion referred to the goal of placing all students with disabilities in the general education classroom with the necessary special education supports and services. None of these terms have ever been in the law and, in fact, have been defined differently in the profession (Filler 1996); for example, Fischer, Schimmel, and Stellman (2007) incorrectly equated 'mainstreaming' with 'inclusion'. The changing interpretation of LRE described by Villa and Thousand has not been accepted by all in the field (Fuchs and Fuchs 1994; Kauffman 1995; Yell 1995). When reacting to challenges to the status quo, Kauffman (1995) claimed a need to 'celebrate a diversity of restrictive environment'.

\section{Least restrictive environment today}

Two of the main requirements of IDEA 04 for children from age 3 to 22 are FAPE and LRE. LRE is considered a rebuttable presumption because it assumes that the child will be in the general education setting and can only be removed from that setting if needed to provide meaningful educational benefit. However, placing a child in a more restrictive educational setting than needed to provide educational benefit would be a violation of FAPE which is a requirement, not a rebuttable presumption. FAPE is defined in the federal regulations governing IDEA as:

$\S 300.17$ Free appropriate public education.

Free appropriate public education or FAPE means special education and related services that: 
(a) are provided at public expense, under public supervision and direction, and without charge;

(b) meet the standards of the SEA, including the requirements of this part;

(c) include an appropriate preschool, elementary school or secondary school education in the State involved; and

(d) are provided in conformity with an individualised education programme (IEP) that meets the requirements of $\S \S 300.320-300.324$.

The most contentious section of FAPE is determining what constitutes appropriate. The first US Supreme Court decision interpreting special education law involved FAPE. In Board of Education v. Rowley (1982), the US Supreme Court clearly stated that FAPE was intended to provide children with a level playing field and ensure that special education services resulted in educational benefit, not maximum benefit.

As previously noted, the LRE requirement is rebuttable, meaning that the presumed regular education placement for a child can be overruled if placement in a more restrictive setting is required to provide FAPE. Absent guidance from the US Supreme Court on an LRE case, several courts have ruled on cases involving placement, balancing the placement in the LRE with the provision of FAPE. The courts have consistently implied or stated that they were determining the LRE for the child of concern, but none of the cases specifically defined LRE. In fact, there is no consistent rule or test for determining cases involving LRE and the Circuit Courts have adopted different standards, i.e. the Roncker portability test, the Daniel R.R. two-part test, the Holland four-factor test or the Hartman three-part test (Yell 2006). Thus, decisions regarding LRE and placements along the continuum can vary by geographic location which makes it imperative that LRE be differentiated from the continuum or when a child moves from one Circuit Court jurisdiction to another, the setting determined to be LRE could change.

\section{Is there more than one least restrictive environment?}

While courts have frequently relied upon professionals to assist with interpretation of educational practices, the LRE language in the body of regulations only weakly supports the contention that there are different LREs for different children. This assumption of different LREs derives much of its significant basis from the Department of Education's discussion of comments to the proposed regulation $\$ 300.116$ published in the 14 August 2006 Federal Register:

This requirement for the continuum reinforces the importance of the individualized inquiry, not a 'one size fits all' approach in determining what placement is the LRE for each child with a disability. The options on this continuum must include the alternative placements listed in the definition of special education under $\$ 300.38$ (instruction in regular classes, special classes, special schools, home instruction in hospitals and institutions). (p. 46587)

Clearly, there is strong legal support for the idea that the regular classroom is the preferred setting but not the required setting in all cases. In Espino v. Besterio (1981), the school district placed a child, whose medical needs required temperaturecontrolled settings, in an air-conditioned plexiglass cubicle in the general education classroom, rather than air-conditioning the entire classroom. The child's parents challenged the decision claiming that the child was not being educated in the 'least restric- 
tive environment appropriate to his individual needs'. The court determined that the cubicle was inappropriate and stated 'if handicapped children are ever to become useful, productive citizens, they must be given an opportunity to experience the world they inhabit'. This statement clearly denotes the importance the court placed on children with disabilities being educated in the general education classroom and the court also noted the important educational goal of socialising children, which could not be adequately accomplished by placing a child in a plexiglass cubicle.

The federal regulations for LRE are contained in Table 1. As can be noted, the LRE section contains several subsections: LRE Requirements which includes the definition of LRE, The Continuum of Alternative Placements, Placements, Nonacademic Settings, and Technical Assistance and Training Activities. A review of the Section 300.114 (2) (i) and (ii) clearly supports the contention that there is one LRE, because it denotes removal from the general education environment only. It does mention alternative placements, but does not place any requirements on removal from the restrictive placement options listed, i.e. special classes and separate schooling beyond the overarching very general requirement that whatever the subsequent placement, it must be reasonably designed to meet the individual needs of the child. Thus, the presumption is that all children with disabilities will be educated in the general education environment and there is absolutely no language regarding removal from a more restrictive setting to the general education environment because the general education environment is the presumed placement and needs no justification, i.e. LRE. The principle that only under very specific conditions should education in a more restrictive setting be considered is well established (A.W. v. Northeast R-1 School District 1987; Daniel R.R. v. State Board of Education 1989; Espino v. Besterio 1981; Oberti v. Board of the Borough of Clementon School District 1993; Roncker v. Walter 1983; Sacramento City School District v. Rachel H. 1994). Even in cases where a more restrictive placement is needed to provide FAPE, there is still the requirement for contact with peers without disabilities to the maximum extent appropriate as denoted in Section 300.117 of the regulations (Renollett by Renollett $v$. Independent Sch. Dist. No. 11, Anoka-Hennepin 2006).

Section 300.115 (see Table 1) describes the continuum of alternative placements that districts must have available, either in the district or through contract, should a child's needs require placement in a setting other than the LRE. Note that the section is not titled the continuum of LREs, and the placements listed begin with the least restrictive (regular class) and proceed to the most restrictive (institutions). The concept of LRE was based on the doctrine of least restrictive alternative (Turnbull and Turnbull 1998). Accordingly, when pursuing a legitimate activity, the government must use the least intrusive alternatives available. Turnbull and Turnbull noted that numerous cases have dealt with governmental intrusion in individual liberties, but cited Wyatt v. Stickney (1972) as particularly important for individuals with disabilities. In that case the court determined that individuals had the right to the least intrusive intervention necessary to achieve habilitation goals. The finding is important and directly relates to education, because it clearly states that if the primary goal is treatment (education), then infringement on rights (deprivation of liberty) is secondary. Thus, the principle does allow the state to remove a child from the LRE, but placement along the continuum must be the least intrusive necessary to provide the child with FAPE. If the child was placed in a setting more restrictive than required to result in meaningful benefit, then both the FAPE and LRE provisions are being violated. So, if a child can receive meaningful educational benefit in the general 
Table 1. Least restrictive environment, final regulations.

Least restrictive environment (LRE)

$\$ 300.114$ LRE Requirements

(a) General:

(1) Except as provided in $\S 300.324(d)(2)$ (regarding children with disabilities in adult prisons), the State must have in effect policies and procedures to ensure that public agencies in the State meet the LRE requirements of this section and $\S \S 300.115-300.120$.

(2) Each public agency must ensure that:

(i) to the maximum extent appropriate, children with disabilities, including children in public or private institutions or other care facilities, are educated with children who are nondisabled; and

(ii) special classes, separate schooling or other removal of children with disabilities from the regular educational environment occurs only if the nature or severity of the disability is such that education in regular classes with the use of supplementary aids and services cannot be achieved satisfactorily.

$\$ 300.115$ Continuum of Alternative Placements

(a) Each public agency must ensure that a continuum of alternative placements is available to meet the needs of children with disabilities for special education and related services.

(b) The continuum required in Paragraph (a) of this section must:

(1) include the alternative placements listed in the definition of special education under $\$ 300.38$ (instruction in regular classes, special classes, special schools, home instruction, and instruction in hospitals and institutions); and

(2) make provision for supplementary services (such as resource room or itinerant instruction) to be provided in conjunction with regular class placement.

\$300.116 Placements

In determining the educational placement of a child with a disability, including a preschool child with a disability, each public agency must ensure that:

(a) The placement decision:

(1) is made by a group of persons, including the parents, and other persons knowledgeable about the child, the meaning of the evaluation data and the placement options; and

(2) is made in conformity with the LRE provisions of this subpart, including $\S \S 300.114-300.118$.

(b) The child's placement:

(1) is determined at least annually;

(2) is based on the child's IEP; and

(3) is as close as possible to the child's home.

(c) Unless the IEP of a child with a disability requires some other arrangement, the child is educated in the school that he or she would attend if nondisabled.

(d) In selecting the LRE, consideration is given to any potential harmful effect on the child or on the quality of services that he or she needs.

(e) A child with a disability is not removed from education in age appropriate regular classrooms solely because of needed modifications in the general education curriculum.

\$300.117 Nonacademic Settings

In providing or arranging for the provision of non-academic and extracurricular services and activities, including meals, recess periods, and the services and activities set forth in $\$ 300.107$, each public agency must ensure that each child with a disability participates with nondisabled children in the extracurricular services and activities to the maximum extent appropriate to the needs of that child. The public agency must ensure that each child with a disability has the supplementary aids and services determined by the child's IEP team to be appropriate and necessary for the child to participate in non-academic settings.

$\$ 300.119$ Technical Assistance and Training Activities

Each SEA must carry out activities to ensure that teachers and administrators in all public agencies:

(a) are fully informed about their responsibilities for implementing $\S 300.114$; and

(b) are provided with technical assistance and training necessary to assist them in this effort. 
education setting with the use of supplementary aids and services, removal to a more restrictive setting where the child may receive even more benefit would not be a sufficient justification for removal and placement in a more restrictive setting.

The continuum itself has been a subject of controversy. Taylor $(1988,2001)$ noted several concerns with the continuum including, among others, that the continuum confuses segregation with intensity of services, and requires that individuals demonstrate 'readiness' to move from more to less restrictive settings. Arguably, aligned with this idea of the continuum requiring that an individual demonstrates competence in order to be placed in a less restrictive environment is an argument by Kauffman and Krouse (1981) that some students are uneducable and therefore not eligible for special education services, a position that illustrates Taylor's concern of the 'readiness' trap. But the debate over educability ended in 1989 with the First Circuit Court ruling in Timothy W. v. Rochester School District. In this case, the Rochester School District claimed that Timothy was 'too' disabled to benefit from special education, so the district should not be required to provide services. However, the Court in its decision noted that the special education law at the time was titled Education for All Handicapped Children Act, and the word 'all' meant 'all', not 'most' or 'all but those who were the most difficult to teach'. The Court further noted that a priority of EAHCA was identification of children with the most severe disabilities who had been denied educational support, and providing education for eligible children like Timothy was a priority. The Court also noted that the experts in the district were the individuals responsible for developing an educational programme and no other child in public school had to demonstrate benefit from education in order to continue receiving services. The Court's recognition of the meaning of the word 'all' was significant and clearly demonstrated the importance of semantics and how imprecise definitions or ambiguous terminology can result in multiple interpretations and unintended, frequently negative, consequences for individuals with disabilities. The LRE controversy may require a similar recognition of the meaning of the word 'least' and more clearly differentiate the LRE from the least restrictive alternative on the continuum of placements. There is nothing in the law that states or even implies that the child must earn his or her way back to the general education setting, a key assumption with the Continuum. In fact, the law always makes the assumption that the child is in the general education setting.

The third section of the regulations for LRE, $\$ 300.116$ (see Table 1) provides guidance for when and how placement decisions must be made. Given that the presumed placement is the general education setting, the regulations note that placement decisions are made on at least an annual basis and be based on the IEP. Thus, placement decisions should be made at the end of the IEP, following development of goals and/or objectives and considerations of whether provision of supplementary aids and services would allow the child to receive FAPE in the general education setting. In practice, particularly for students placed in settings other than the regular classroom, many IEP teams succumb to the erroneous and illegal practice of determining placement prior to the development of annual goals/objectives. They write IEPs to serve the child in the current restrictive setting due to a belief that it is the child's LRE. Such a presumption leads to a practice that fails to comply with the LRE requirements and tends to limit considerations of supplementary aids and services that could be provided in the regular education environment; thereby, affording the child with an opportunity to benefit from education in the LRE. Part (3)(c) of this section provides further support that the LRE is the general education setting by noting that the child 
should attend the school he or she would attend if nondisabled, unless the IEP team determined otherwise. Part (3)(e) also clearly states that a child cannot be removed solely due to the fact that modifications in the general education curriculum may be needed. The remaining sections governing LRE, in Table 1, indicate that the LRE provision extends to non-academic areas that are part of the general education environment in addition to requirements that the child have access to typically developing peers to the maximum extent appropriate. School districts must also provide training necessary to ensure appropriate implementation of the LRE requirements.

Table 2 contains items from the regulations regarding contents of the IEP. A review of the requirements also demonstrates the presumption that children with disabilities are educated with typically developing peers and have access to the general education curriculum. The section notes that the IEP team must explain any removal from the general education setting or non-academic settings. It is important to note that the regulations require justification for removal from the general education setting not 'the child's LRE'. If there were, in fact, different LREs for different children and removing a child from his or her LRE would be detrimental, then it would follow that the regulations would require justification for removal from the restrictive setting and placement in the general education setting.

\section{Special considerations - preschool age students, infants and toddlers}

All of the requirements of IDEA 04, also called Public Law 108-446, including the LRE requirements, are applicable to children from age three to six with some additional specificity provided in Section 614. Whereas for children from age 6 to 22, the IEP is to include 'information related to enabling the child to progress in the general education curriculum', the requirement for preschool age children the IEP is to include a focus upon participation in 'appropriate activities'. The actual setting in which children with disabilities from age three to six may be placed includes a range of options from regular kindergarten to private preschools and or childcare programmes. Some confusion has arisen over the range of options available to school districts that do not operate pre-kindergarten programmes for students without disabilities, by far the majority of those in the USA. No doubt much of this confusion has arisen from a decision to eliminate the all-explanatory notes from the rules and regulations that govern the administration of the law. This removal of notes was first made

Table 2. IEP contents.

300.320(a)(4) A statement of the special education and related services and supplementary aids and services, based on peer-reviewed research to the extent practicable, to be provided to the child, or on behalf of the child, and a statement of the programme modifications or supports for school personnel that will be provided to enable the child.

(ii) To be involved in and make progress in the general education curriculum ... and to participate in extracurricular and other non-academic activities; and

(iii) To be educated and participate with other children with disabilities and nondisabled children in the activities described in this section;

(5) An explanation of the extent, if any, to which the child will not participate with nondisabled children in the regular education environment and in the activities described in paragraph (a)(4) of this section. 
in 1999 with the publication of the rules and regulations for the 1997 amendments of IDEA (Public Law 105-17). Prior to that time a note to $\$ 300.550-300.556$ (LRE) suggested that kindergarten programmes in elementary schools, private preschools and head start programmes would be acceptable alternatives to the clearly nonmandated creation of new programmes in the public schools for typically developing children. It was not until after the publication of the Notice of Proposed Rule Making (NPRM) for Public Law 105-17, which did include the earlier note regarding acceptable LRE alternatives for preschool age children, that the decision was made to remove all notes from the final regulations. The removal was objected to by many of those who commented but the decision to remove all clarifying notes prevailed and was carried over to the current set of rules and regulations for Public Law 108-446. Nevertheless, the range of options for placement available clearly includes all that were mentioned in the earlier regulations for Public Law 101-476 (1991) and in the NPRM for Public Law 105-17.

Placement of a three-year-old with a significant developmental delay in a regular kindergarten classroom is an often used answer to the LRE question, no doubt because of the relative availability of kindergarten classrooms and the difficulty of developing interagency agreements between public schools and private day care and preschool programmes that would allow for an alternative placement and still insure the appropriate delivery of special education and related services. The determination that a kindergarten classroom is the LRE for a three- or four-year-old child with disabilities is strictly a legal decision, but it is a highly questionable practice from the perspective of developmental appropriateness. A better option, and one often used, is placement in an age appropriate public or private preschool programme (Filler and Xu 2006).

The LRE requirement for infants and toddlers from birth through three years of age is expressed in both law and regulations somewhat differently but is, nonetheless, clearly present. Part C of Public Law 108-446 Section 632 (4) (G) states that early intervention services 'to the maximum extent appropriate are provided in natural environments, including the home, and community settings in which children without disabilities participate'. This requirement is often quite erroneously interpreted to mean that the natural environment is only the home. It is becoming increasingly more common to find young infants and toddlers receiving early intervention services in the same childcare settings with their typically developing peers. Again, this requires some form of interagency agreement between the designated Part $\mathrm{C}$ provider and the private provider. The agency responsible for the provision of early intervention services must insure the provision of all required services specified in the individualised family service plan regardless of setting. This is yet another example of the more general principle that needed special education and related services; and in the case of a child below the age of three years, early intervention services are to follow the child regardless of placement and should not constitute the basis for a determination of placement.

\section{Summary and conclusion}

LRE with all of its sometimes complicated and even contentious considerations is one of the most important aspects of IDEA. Throughout the history of the USA there are critically important reminders that we must protect the right to freely associate with our peers. We have witnessed during the 1960s the use of armed troops to insure mandated access to public schools for African-American children and we have seen 
that the notion of separate but equal cannot be defended. There are widely accepted assumptions fundamental to our most basic values of what democracy means. Access to a FAPE is central among those assumptions and is rooted firmly in the constitution (Sailor et al. 1989; Thomas and Rapport 1998; Turnbull, Stowe, and Huerta 2007). When we create, even unintentionally, barriers to participation that require some standard of acceptability be met before access is granted, history teaches us that we must do so with the utmost care.

As numerous authors have noted placements for students with disabilities have traditionally meant a setting removed from the regular education classroom or, even, a segregated centre far from home or a less well-funded and poorly staffed programme (Taylor 2001; Turnbull 2006). Prior to the passage of Public Law 94-142 the 'presumption' was placement in a programme with little or no contact with typically developing peers but the presumption changed dramatically to one that emphasises a clear preference for the regular education classroom as the least restrictive point on a continuum of alternatives from least to most restrictive. Acknowledgement of the regular classroom as the least restrictive placement, on the continuum of possible placements, does not in any way mean that the regular classroom is always the appropriate placement for every student with a disability. Placement in the least restrictive setting is, as many have noted, a rebuttable presumption (Evangelista 1998; Rothstein 2000; Turnbull, Stowe, and Huerta 2007; Yell 1998, 2006). If whatever placement deemed by the duly constituted team is viewed as being the least restrictive placement there would be no need to even consider a rebuttal. We have fallen into the illogical and semantically absurd notion that in order to justify a placement in a restrictive setting we must redefine it to be the least restrictive environment for the child who may well be appropriately placed there. LRE then becomes whatever the current setting is determined and participation in the general education classroom becomes an unnecessary goal. This view could lead IEP teams into the unethical and illegal practice of predetermining placement and writing an IEP for a child in a particular restrictive setting, rather than writing the IEP for the specific skills the child needs under the assumption that the child will be in the general education setting. Predetermining placement would be a violation of the FAPE requirements of IDEA as would placing a child in a more restrictive placement along the continuum than needed to meet the educational needs of the child (Yell 2006).

\section{Notes on contributors}

Keith J. Hyatt, EdD, is an associate professor of special education at Western Washington University. His interests include special education law, inclusion, controversial practices and early childhood special education.

John Filler, $\mathrm{PhD}$, is a professor of early childhood special education at the University of Nevada, Las Vegas. His interests and research are focused upon the inclusion of young students with disabilities in a variety of educational and community environments, social skill development in young children and issues of law as related to the rights of people with disabilities.

\section{References}

Assistance to States for the Education of Children with Disabilities and Preschool Grants for Children With Disabilities; Final Rule, 32 C.F.R. Parts 300 and 301 (2006).

A.W. v. Northeast R-1 School District, 813 F.2d 158 (8th Cir. [1987]).

Baird, M.J. 2006. The LRE continuum: Appropriate placement decisions under the IDEA and

NCLB. Palm Beach Gardens, FL: LRP. 
Biklen, D. 1982. The least restrictive environment: Its application to education. Child and Youth Services 5: 121-44.

Blatt, B., and F. Kaplan. 1966. Christmas in purgatory: A photographic essay on mental retardation. Boston, MA: Allyn \& Bacon.

Board of Education v. Rowley, 458 US 176, 102 S. Ct. 3034, 73 L. Ed. 2 d 690 (1982).

Brown v. Board of Education of Topeka, 347 US 483 (1954).

Daniel, R.R. v. State Board of Education, 874 F.2nd 1036 (5th Cir. [1989]).

Danile, P.T.K. 1997. Educating students with disabilities in the least restrictive environment: A slippery slope for educators. Journal of Educational Administration 35: 397-410.

Deno, E. 1970. Special education as developmental capital. Exceptional Children 37: 229-37.

Education for All Handicapped Children Act, 20 USC, 89 Stat. 773 (1975).

Espino v. Besterio, 520 F. Supp. 905 (S.D. Tex. [1981]).

Evangelista, A.D. 1998. Full inclusion and the Individuals with Disabilities Education Act: A clear and convincing standard for cases involving the least restrictive environment provision. National Italian American Bar Association Journal 6: 45-70.

Filler, J. 1996. A comment on inclusion: Research and social policy. Society for Research in Child Development Social Policy Report 10, nos. 2-3: 31-3.

Filler, J., and Y. Xu. 2006. Including children with disabilities in early childhood education programs: Individualizing developmentally appropriate practices. Childhood Education 83: 92-8.

Fischer, L., D. Schimmel, and L.R. Stellman. 2007. Teachers and the law. 7th ed. Boston, MA: Pearson Education.

Fuchs, D., and L.S. Fuchs. 1994. Inclusive schools movement and the radicalization of special education reform. Exceptional Children 60: 294-309.

Hamre-Nietupski, S., and J. Nietupski. 2008. Integral involvement of severely handicapped students within regular public schools. Research and Practice for Persons with Severe Disabilities 33, no. 3: 157-65.

Heward, W.L. 2006. Exceptional children: An introduction to special education. 8th ed. Upper Saddle River, NJ: Pearson Education.

Individuals with Disabilities Education Improvement Act of 2004, 20 USC 1400 et seq. (2004).

Kauffman, J.M. 1995. Why must we celebrate a diversity of restrictive environments? Learning Disabilities and Practice 10: 225-32.

Kauffman, J.M., and D.P. Hallahan. 2005a. The illusion of full inclusion: A comprehensive critique of a current special education bandwagon. Austin, TX: PRO-ED.

Kauffman, J.M., and D.P. Hallahan. 2005b. Special education: What is it and why we need it? Upper Saddle River, NJ: Pearson Education.

Kauffman, J.M., and J. Krouse. 1981. The cult of educability: Searching for the substance of things hoped for; the evidence of things not seen. Analysis and Intervention in Developmental Disabilities 1: 53-60.

Mills v. District of Columbia Board of Education, 348 F. Supp. 866 (D.D.C. 1972); contempt proceedings, EHLR 551:643 (D.D.C. 1980), (1972).

Oberti v. Board of Education of the Borough of Clementon School District, 995 F.2d 1204 (3rd Cir. [1993]).

Osgood, R.L. 2008. The history of special education: A struggle for equality in American public schools. Westport, CN: Praeger.

Palley, E. 2006. Challenges of rights-based law: Implementing the least restrictive environment mandate. Journal of Disability Policy Studies 16: 229-35.

PARC v. Commonwealth of Pennsylvania, 334 F. Supp. 1257 (E.D. Pa. 1971); 343 F. Supp. 279 (E.D. Pa. [1972]).

Petrou, A., P. Angelides, and J. Leigh. 2009. Beyond the difference: From the margins to inclusion. International Journal of Inclusive Education 13, no. 5: 439-48.

Pierce v. Society of the Sisters of the Holy Names of Jesus and Mary. 268 US 510 (1925).

Plessy v. Ferguson, 163 US 537, 16 S. Ct. 1138, 41 L. Ed. 256 (1896).

Rehabilitation Act of 1973, Section 504 Regulations, 34 C.F.R. $\$ 104.1$ et seq.

Renollett by Renollett v. Independent Sch. Dist. No. 11, Anoka-Hennepin, 42 IDELR 201 (D. Minn. 2005), aff'd. 45 IDELR 117 (8th Cir. [2006]).

Reynolds, M. 1962. A framework for considering some issues in special education. Exceptional Children 28: 367-70. 
Rivera, G. 1972. Willowbrook: A report on how it is and why it doesn't have to be that way. New York: Vintage Books.

Roncker v. Walter, 700 F. 2nd 1058 (6th Cir. 1983), cert. denied, 464 US 864, 104 S. Ct. 196, 78 L. Ed. 2d 171 (1983).

Rothstein, L.F. 2000. Special education law. 3rd ed. New York: Longman.

Sacramento City School District v. Rachel H., 14 F.3d 1398 (9th Cir. 1994), cert. denied sub nom., Sacramento City Unified School Dist. v. Holland, 114 S. Ct. 2679 (1994).

Sailor, W., J.L. Anderson, A.T. Halvorsen, K. Doering, J. Filler, and L. Goetz. 1989. The comprehensive local school: Regular education for all students with disabilities. Baltimore, MD: Paul H. Brookes.

San Antonio School District v. Rodriguez, 411 US 1 (1973).

Taylor, S.J. 1988. Caught in the continuum: A critical analysis of the principle of the least restrictive environment. Journal of the Association for Persons with Severe Handicaps 13: $45-53$.

Taylor, S.J. 2001. The continuum and current controversies in the USA. Journal of Intellectual and Developmental Disability 26: 15-33.

Thomas, S.B., and M.J.K. Rapport. 1998. Least restrictive environment: Understanding the direction of the courts. Journal of Special Education 32: 66-78.

Thomazet, S. 2009. From integration to inclusive education: Does changing the terms improve practice? International Journal of Inclusive Education 13, no. 6: 553-63.

Timothy, W. v. Rochester School Dist., 559 EHLR 480 (D.N.H. 1988) (875 F.2d 954 (1st Cir. 1989) cert. denied, 493 US 983, (1989).

Turnbull, A.P. 2006. Exceptional lives: Special education in today's schools. Upper Saddle River, NJ: Merrill/Prentice Hall.

Tumbull, H.R.I., M.J. Stowe, and N.E. Huerta. 2007. Free appropriate public education: The law and children with disabilities. 7th ed. Denver, CO: Love Publishing.

Turnbull, H.R.I., and A.P. Turnbull. 1998. Free appropriate public education. 5th ed. Denver, CO: Love Publishing.

Villa, R.A., and J.S. Thousand. 2003. Making inclusive education work. Educational Leadership 61: 19-23.

Wyatt v. Stickney, 344 F. Supp. 373; 1972 US Dist. LEXIS 14201 (United States District Court for the Middle District of Alabama, Nothern Division 1972).

Yell, M.L. 1995. Least restrictive environment, inclusion and students with disabilities: A legal analysis. Journal of Special Education 28: 389-404.

Yell, M.L. 1998. The legal basis of inclusion. Educational Leadership 56: 70-3.

Yell, M.L. 2006. The law and special education. 2nd ed. Upper Saddle River, NJ: Pearson Education. 